\title{
ANALYSIS OF BENEFICIARIES SATISFACTION MEASUREMENT AT BAZNAS SCHOLARSHIP AGENCY
}

\author{
Muhammad Fadhil \\ BAZNAS Scholarship Agency, Jakarta \\ muhamad.fadil94@gmail.com
}

\begin{abstract}
The service of the Organization must be excellent to give satisfaction to beneficiaries. The National Board of Zakat (BAZNAS) through the BAZNAS Scholarship Institution (LBB) have a program to give a scholarship for Indonesian student in Indonesia, Malaysia, Egypt, and India. To support this program, LBB must have good scholarship management and communication. This study aims to identify satisfaction of communication service and scholarship management from BAZNAS Scholarship Beneficiaries using analysis of reliability, Top-Two Box method, and correlation test using SPSS application for data processing. The data was collected through an online questionnaire. A total of 321 were the research samples. The results of Cronbach's Alpha test on the questionnaires and data show that the data are reliable in this study (Cronbach's Alpha value $=0.922$ ). Through the analysis using the Top-Two Box method, prove that LBB has good satisfaction from beneficiaries. The overall value of participant's satisfaction is $98.18 \%$ was the satisfaction of communication service higher than scholarship management. The highest score of satisfaction item is language ability and the lowest score is the punctuality of scholarship distribution. In this research, we analyze the correlation of gender, age, and level of education with the results are $0.525 ; 0.401$; and 0.927 . With the high satisfaction results, we hope our Beneficiaries can be a loyal Muzakki in the future.
\end{abstract}

Keywords: Satisfaction, BAZNAS, Service, Top Two Box

\begin{abstract}
Abstrak: Pelayanan dari suatu organisasi harus bagus agar dapat memberikan kepuasan kepada penerima manfaat. Badan Amil Zakat Nasional (BAZNAS) memalui Lembaga Beasiswa BAZNAS (LBB) memiliki program beasiswa untuk Mahasiswa Indonesia yang ada di Indonesia, Malaysia, Mesir dan India. Untuk mendukung program ini, LBB harus memliki pengelolaan beasiswa dan komunikasi yang baik. Penelitian ini bertujuan untuk mengidentifikasi pelayanan komunikasi dan pengelolaan beasiswa dari penerima manfaat Lembaga Beasiswa BAZNAS menggunakan analisa realibilitas, metode Top Two Box, dan uji korelasi menggunakan aplikasi SPPS dalam pengolahan datanya. Data-data didapatkan melalui pengisian kuisioner secara daring. Total sampel yang diteliti adalah 321. Hasil dari uji Croncbach Alpha terkait kuisioner dan data menunjukkan bahwa data ini dapat digunakan dalam penelitian ini (nilai Croncbach Alpha = 0,922). Dengan menggunakan metode Top Two Box, membuktikan bahwa LBB telah mendapatkan penilaian kepuasan yang baik dari penerima manfaat. Secara keseluruhan tingkat kepuasan dari penerima manfaat adalah $98.18 \%$ dengan kepuasan pelayanan komunikasi lebih tinggi dari pengelolaan beasiswa. Aspek yang mendapat nilai paling tinggi adalah peggunaan tata Bahasa, sedangkan aspek yang mendapat nilai terendah adalah ketepatan waktu pemberian beasiswa. Dalam penelitian ini juga dianalisa korelasi antara jenis kelamin, usia, dan Pendidikan terhadap tingkat kepuasan dengan hasil masing-masing $0.525 ; 0.401$; dan 0.927. Dengan tingginya tingkat kepuasan ini kami berharap para penerima manfaat dapat menjadi Muzaki yang loyal di masa yang akan datang.
\end{abstract}

Kata Kunci: Kepuasan, BAZNAS, Pelayanan, Top Two Box 


\section{A. Introduction}

One of the problems every nation in the world is poverty. In Indonesia, we have same problem. Poverty rate until March 2020 is about 9,8\% or more than 26 million people (BPS ,2020). Its increase 1,6 million from September 2019. Pandemic Covid-19 is suspected to be one of the factors in increasing poverty rate. Poverty is one aspect that all of the people in the world concern and include on Sustainable Development Goals (SDGs). Poverty is caused because people's purchasing power is lower than the established poverty line. The poor usually have limited access, including housing, clothing, lighting, education, health, purchasing power, and transportation. Similar limitations will affect the offspring if there is no effort to open these accesses individually. In some conditions, students from poor families have difficulty paying tuition fees, so that the time that can be optimized for studying is used for other activities such as part-time work. In fact, some students have to leave and drop out of college.

In this case, Islam as a rahmatan lil alamin religion has an important role in alleviating poverty through Zakat. Zakat is a specific property that is issued when it has reached the conditions set in accordance with the rules of religion, issued to 8 asnaf recipients of zakat. According to the language the word "zakat" means to grow, develop, fertile or increase. Zakat comes from the form of the word "zaka" which means holy, good, blessing, growing, and growing. It is called zakat, because it contains the hope of obtaining blessings, purifying the soul and nurturing it with various virtues. The meaning of growing in the meaning of zakat shows that issuing zakat as a reason for the growth and development of property, the implementation of zakat results in many rewards. While the holy meaning shows that zakat is to purify the soul from ugliness, falsehood and purification from sins. In the Qur'an it is mentioned, "Take zakat from some of their property, with that zakat you cleanse and purify them" (QS. At-Taubah [9]: 103).

The National Zakat Board (BAZNAS) is an official and the only one formed by the government based on Presidential Decree No. 8 of 2001 which has the task and function of collecting and distributing zakat, infaq and alms (ZIS) at the national level. In 2018, BAZNAS formed the BAZNAS Scholarship Agency which aims to provide scholarship assistance to the poor. The formation and function of BAZNAS Scholarship Agency is in line with the Indonesian Ulama Council (MUI) fatwa Number Kep-120 / MUI / II / 1996 which states that zakat is allowed for scholarships with the following considerations:

1. Academic achievement,

2. Prioritized for the poor,

3. Studying science that is useful for the Indonesian people.

Commissioner of BAZNAS, Nana Mintarti, said that BAZNAS has five programs, including education and education sector has a portion of 20-25 percent of the total allocation of funds collected by BAZNAS. She believes that the good quality of education can improve the welfare of the people (Mintarti, "Potrait and Challenge"). The presence of BAZNAS Scholarship Agency has a big mandate, which is to ensure the continuity of education programs for the underprivileged / poor as an inter-generational accountability as well as to prepare the next generation of the nation who has the depth of knowledge and moral dignity. Educational scholarship assistance is not enough to cover tuition fees, but must also be accompanied by programs that encourage the improvement of the quality of human resources. This is in line with one of the targets and functions of zakat distribution, which is to prioritize the improvement of human resources. The program of BAZNAS Scholarship Agency are:

\section{Beasiswa Cendekia BAZNAS (BAZNAS Scholar Scholarship)}

This program focused on bachelor degree education. BAZNAS Scholarship Agency has collaboration in Indonesian University and Abroad.

a. BAZNAS Scholar Scholarship - Indonesia

In this program, BAZNAS collaborate with more than 80 universities in Indonesia. The things that are required to get this scholarship are the student who are poor and in $5^{\text {th }}$ 
grade. The assistance provided are Tuition Fee a maxium of IDR 4,000,000 and allowance IDR 400,000 each month. Scholarship recipients get this scholarship for 2 years (4 Semesters). In addition, scholarship recipients also receive coaching from a mentor who is appointed directly by the Universities. Coaching form mentor to prepare scholarship recipients to be able to contribute to society. These are 3 categories of this program, Young Activist, Young Entrepreneur, and Young Role Models. The Mentor whose chosen by University based on the passion of scholarship recipients. In 2018-2020 period, we have 750 scholarship recipients and in 2020-2022 period, we have 478 scholarship recipients.

b. BAZNAS Scholar Scholarship - Albukhary International University, Malaysia In this program, BAZNAS collaborate with Albukhary International University Malaysia. The program gives to high school graduates who are classified as poor. The assistance provide from BAZNAS are Passport Fee, Visa Fee, Registration Fee, Personal Bond, Education Malaysia Global Service (EMGS) Fee (yearly), and also a ticket flight to Malaysia. The assistance provide by Albukhary International University are Tuition Fee, Accommodation (Free Hostel) and Meal Allowance. Until now, we have a total 84 scholarship recipients in Malaysia.

c. BAZNAS Scholar Scholarship - Al Azhar University, Egypt

In this program, BAZNAS provide to high school graduates who pass the selection from Ministy of Religion Indonesia. The assistance provide are departure ticket assistance IDR $4,200,000$ and allowance IDR 700,000 each month. Scholarship recipients get this scholarship for 2 years (4 Semesters). In addition, BAZNAS collaborate with Indonesian Student Association in Egypt to give coaching to learn about the Arabic language and memorizing the Quran. Total 40 scholarship recipients in Egypt.

d. BAZNAS Scholar Scholarship - Aligarh Muslim University, India

In this program, BAZNAS collaborate with the Superteache Institute to give scholarship for high school graduate who are classified as poor. The assistance provide are departure ticket assistance and allowance IDR 1,000,000 each month. Total 5 scholarship recipients in India.

2. Beasiswa Kaderisasi Seribu Ulama (The Thousand Ulama Cadre Scholarship)

In this program, BAZNAS collaboration with Indonesian Ulama Council (MUI) to give scholarship for post graduate. The aim on this program is a Region-Cadre MUI. The provide assistance are Tuition Fee, Research Fee, Book Assistance, and Exam Fee. In addition, BAZNAS give a coaching for scholarship recipients.

3. Beasiswa Riset Zakat (Zakat Research Scholarship)

This program aims to provide the research of zakat for undergraduate and postgraduate student. The reseach must about Zakat. The cost given for this research are IDR 4,000,000 for undergraduate (S1), IDR 7,000,000 for postgraduate (S2) and IDR 10,000,000 (S3)

\section{Beasiswa Kemitraan (Partnership Scholarship)}

One of the goals of national education has been explicitly stated in the preamble to the 1945 Constitution, namely to educate the nation's life. One of the efforts to achieve this goal is through programs scholarships, to ensure the continuity of education of the participants to become quality graduates. The current direction of the scholarship needs to be collaborated to achieve a wider impact. Scholarship Institution Apart from distributing scholarships directly to mustahik, BAZNAS also collaborates with several institutions that have expertise in their fields to reach out to groups that also need. BAZNAS collaborate with 4 partners with different specification

a. Hoshizora Foundation Yogyakarta, with the program "Dream Scholarship for State Children - Central and Eastern Indonesia Region"

b. Yayasan Gapai Indonesia Surakarta, with the program "Gapai Scholarship for Children with Special Needs" 
c. The Solo Community-Based Rehabilitation Development and Training Center (PPRBM Solo), with the program "Building Difabel and Families with Disabilities Empowered"

d. Bandung Education Concerned Family Association (Kerlip), with the program "Youth Pioneers Kindness From Disadvantaged Areas in Pandeglang "

\section{Alumni Development Program}

Before BAZNAS Scholarship Agency was formed in 2018, BAZNAS have an education program like Satu Keluarga Satu Sarjana (SKSS) and also The Thousand Cadre of Ulama. Until 2017, BAZNAS has alumni of more than 200 people. To broadcast zakat, BAZNAS empowers alumni to hold workshops and fill office lectures.

\section{Event LBB}

In addition to scholarship programs, BAZNAS Scholarship Agency also organizes events that showcase the best work of BAZNAS scholarship recipients or Baznas scholarship alumni such as Book Review and Inspiring Talkshow.

\section{Voluntary Activities}

In contributing to education, BAZNAS also opens opportunities for general students including scholarship recipients to be able to contribute to society such as psychosocial when a disaster occurs and education related to Covid 19.

With all of the program, BAZNAS hope the student who classified as poor or we called Mustahik can turn into Muzakki (People who give Zakat) in the future. To support this program, BAZNAS must have good scholarship management and communication service. Good communication service and scholarship management are expected to increase public trust for Zakat Management also BAZNAS. So, we need to calculate the Satisfaction of Beneficiaries and analyze that. In this research We analyzed satisfaction from 3 program:

a. Beasiswa Cendekia BAZNAS (Baznas Scholar Scholarship)

b. Beasiswa Kaderisasi Seribu Ulama (The Thousand Ulama Cadre Scholarship)

c. Beasiswa Riset Zakat (Zakat Research Scholarship)

\section{B. Theoretical Review}

\section{Zakat Empowerment}

The definition of empowerment according to Mc. Ardle (Hikmat, 2010), is the decisionmaking process of people who consequently carry out the decisions that have been taken. In the past, zakat was probably mostly socialized with the rich like property owner, entrepreneur, etc. Nowadays the total potential of zakat is getting wide and bigger. This has an impact on management, especially in the aspect of mobilization. One of the concepts that has been carried out by BAZNAS is commonly called productive zakat and consumptive zakat. The Zakat Empowerment is the right solution in alleviating the problem of poverty, education for children of poor families, through educational scholarships for those who do not have access to education. The aim is to improve the quality of human resources and simultaneously encourage those who receive educational scholarships to be productive which is facilitated through training, coaching, mentoring and so on so that they get out of educational inequality (Abu Bakar, 2015).

Qardhawi divides the two objectives of the teachings of zakat, namely the goal for individual life and the goal for social life. The first objective includes purification of the soul from being stingy, developing the nature of giving or giving, developing good morals, healing the heart from excessive love for the world, developing inner wealth and cultivating sympathy and love for fellow humans. In other words, the essence of all these goals is education which aims to enrich the human soul with spiritual values that can elevate human dignity beyond the dignity of objects and eliminate the nature of materialism in humans. The second objective has an impact on societal life at large. In terms of community life, zakat is a part of the social security system in Islam (Qardawi, 2011) 
Indonesia is a country with the largest Muslim population in the world. In 2013 the total population of Indonesian Muslims reached $87.21 \%$ according to Indonesian Ministry of Religion (2013). It can be ascertained that with the largest Muslim population, Indonesia also has huge zakat potential. Based on Baznas research, Bogor Agricultural Institute (IPB), and the Islamic Development Bank (IDB), the national zakat potential is IDR 217 trillion. So far, Indonesia's zakat collection has only reached about IDR 10 trillion (Center of Strategic Studies - The National Zakat Board, 2020). This data shows that there is still a lot of potential for zakat that needs to be explored. One of the efforts to optimize zakat is education. with good education zakat can grow and provide wider benefits.

There are several factors that can cause less than optimal zakat (Ma'sum, 2015). First. Indonesian people still have low knowledge about zakat, the laws of zakat management, and management institutions of zakat. The second is zakat management institution's act was not active in three aspects, professional management tasks, transparent, and accountable. And the last is amil zakat is chosen by the government in general are retired religious officials and community leaders and official's active government.

\section{Service Quality}

According to Joseph Juran, quality is fitness for use, this means that a product or service should match what is needed or expected by the user. Based on another opinion, quality is a subjective assessment of the "customer" this determination is determined by the "customer" perception of products and services. To fulfill customer or beneficiary's satisfaction, organization or company need to improve their service quality. According to Rahmawati, Zain, and Yahya, Analisa Statistik Kepuasan Pelanggan, 1, service quality is fulfillment of customer needs and desires. The requirements on increasing service quality are needs or expectations expressed are usually implied or mandatory.

These are some factor to increase service quality according to Lauw and Kunto, Analisa Pengaruh Kualitas Layanan, 2

a. Reability, to provide the promised services reliably and accurately.

b. Responsiveness, to help customers and provide services quickly.

c. Assurance, knowledge, manners, and the ability of employees to generate confidence and trust.

d. Empathy, care and attention given to beneficiaries

e. Tangible, the appearance of physical facilities, installed equipment, personnel, and materials. This also applies to zakat institutions which must provide the best service to muzakki and mustahik (beneficiaries).

\section{Scholarship Management}

Education is a very complex activity. Almost all dimensions of human life are involved in the educational process, there are elements of politics, economic, legal, social, cultural, health, climate, psychological, sociological, ethical, aesthetics etc. Nowadays, education faced four big challenge. First is challenge on increase national productivity, economic distribution, and suistainable development. Other points are about transformation on human resource development, increasing command of Information, Communication and Technology, and neocolonialism on science and technology. But not everyone has access to proper education. The rate of student dropout is high.

To reduce the dropout rate for student, government, foundation, or institution made an effort to give assistance for a student who classified as poor or have a good academic achievement. This assistance needs to help poor people to get a proper education and increase their confidence. In education, motivation is very important. With scholarship, student will get motivation to study. Scholarship always linked by academic achievement. To optimize scholarship program, foundation or institution must pay attention to scholarship management. Enactive that assistance that beneficiaries get is enough, assistance distribution on time, and 
requirement to get scholarship is clear are some factor thah must be conciderd to increase quality of scholarship management. In addition, scholarship will give until $75 \%$ motivation rate (Asmirawati, Pengaruh Pemberian Beasiswa, 63).

\section{Customer Satisfaction}

Customer satisfaction is the main goal for every service. Customer satisfaction (consumer) can be defined as the ability of a product or service to meet or exceed expectations and desires of consumers. There are two indicators in examining satisfaction namely customer expectations and customer perceptions of a given company. Customer satisfaction is a feeling happy or disappointed someone showed up after comparing between perceptions or impressions of the performance or results of a product and their hopes (Kotler).

In determining the level of customer satisfaction, there are factors that must be considered by the company. These are product quality, service quality, and emotion. Consumer will be satisfied if their review show that the product has a good quality and get a good service.

These are method that can be used to measuring customer satisfaction:

a. Complaints and suggestions system, this information can be a new resolution or idea to improve their product or service

b. Ghost Shopping, hiring several people to act or act as a potential buyer, in social program as a beneficiary, then reports its findings regarding the strengths and weaknesses of the foundation's or competitors-based products their experience in purchasing these products

c. Lost Customer Analysis, foundation or organization must keep contact with their beneficiaries. Lost Customer (Beneficiaries) to give a good performance have a bad impact on the foundation.

d. Customer Satisfaction Survey, foundation or organization make a survey with telephone, interview, or online questionnaire. They will get a response and feedback from beneficiaries.

\section{Methods}

\section{Sampling Population}

This research was conducted for BAZNAS Scholarship Program participants who took part in September - October 2020. The primary data used in this study was data obtained from an online survey using google form for all respondents. Selection of respondents using purposive sampling method (nonprobability sampling). Total of beneficiaries of BAZNAS Scholarhsip Agency of program BAZNAS Scholar Scholarship, The Thousand Cadre of Ulama and Zakat Research Scholarship from 2018 is 1469 people.

\section{Determination of variables}

Analysis of the calculation of related index with satisfaction to determine the level of beneficiary satisfaction. In getting the satisfaction index customer aspects assessed in the questionnaire in the form of:

a. Communication Service

1) Provide scholarship program information

2) Quick response to questions that arise from beneficiaries

3) Provides answers / solutions to questions that arise from beneficiaries

4) Data verification with politely not coercion

5) Administrative completeness is checked carefully

6) Giving suggestions and advice in providing services

7) Requests for incomplete administrative documents with good communication

8) Face-to-face survey or making contact by telephone

9) In conducting surveys, program managers do it in polite language

10) Communication with program managers is also carried out when there is a problem with the mustahik. 
b. Scholarhsip Management

1) Scholarships distribution on time

2) The coaching program is very helpful

3) Scholarship requirements can be fulfilled easily

4) The scholarship form can be filled out easily

5) Scholarships are accepted according to the amount that is informed

6) Scholarships are sufficient to meet needs

7) Coaching is carried out according to the time schedule

8) There is evidence of assistance / disbursement of funds

9) Program manager is always accompany during the scholarship period

10) Customer satisfaction is measured using 19 statement above. Each item using 4 Likert scale levels from very bad to very good.

\section{Data Reliability}

The calculation of the reliability value can be calculated with the alpha coefficient value. The alpha coefficient value is used to see the level of data reliability to be used in this study. The coefficient alpha (cronbach's alpha) was calculated with the help of SPSS software.

\section{Top-Two Box Analysis}

Top Two Boxes analysis is a method combine the percentage of respondents' answers in Likert scale. Top Two Boxes analysis is used for find out how the comparison between the numbers bottom option (score 1,2) namely the scale is not very agreeing and disagree with the top option (score 3,4$)$ or fTi, which is the agree and strongly agree scale. The formula is:

$$
\mathrm{TTB}=\sum \frac{\mathrm{fTi}}{\text { Total Responden }} \times 100 \%
$$

\section{Correlative Test}

The Correlative test is measurement the correlation of variable with results of satisfaction using SPSS application for data processing. Variable is gender, age, and level of education.

\section{Results and Discussion}

In this research, data was collected by online questionnaire. The list of scholarship recipients who filled out the questionnaire is as follows

Table 1. Percentage of scholarship recipients who filled out the questionnaire

\begin{tabular}{|c|c|c|c|c|}
\hline No. & Program & $\begin{array}{c}\text { Total } \\
\text { Beneficiaries } \\
\end{array}$ & $\begin{array}{c}\text { Online } \\
\text { Questionnaire }\end{array}$ & $\begin{array}{c}\text { Percentage } \\
(\%)\end{array}$ \\
\hline 1 & $\begin{array}{l}\text { BAZNAS Scholar Scholarship } \\
\text { - Indonesia }\end{array}$ & 1228 & 221 & $18 \%$ \\
\hline 2 & $\begin{array}{l}\text { BAZNAS Scholar Scholarship } \\
\text { - AIU }\end{array}$ & 84 & 42 & $50 \%$ \\
\hline 3 & $\begin{array}{l}\text { BAZNAS Scholar Scholarship } \\
\text { - Al Azhar }\end{array}$ & 40 & 21 & $53 \%$ \\
\hline 4 & $\begin{array}{l}\text { BAZNAS Scholar Scholarship } \\
\text { - AMU }\end{array}$ & 5 & 4 & $80 \%$ \\
\hline 5 & $\begin{array}{l}\text { The Thousand Ulama Cadre } \\
\text { Scholarship }\end{array}$ & 20 & 12 & $60 \%$ \\
\hline 6 & Zakat Research Scholarship & 92 & 21 & $23 \%$ \\
\hline & Total & 1469 & 321 & $22 \%$ \\
\hline
\end{tabular}




\section{Data Reliability}

Before analyzing data, we need to calculated alpha value. The results of chronbac's alpha value

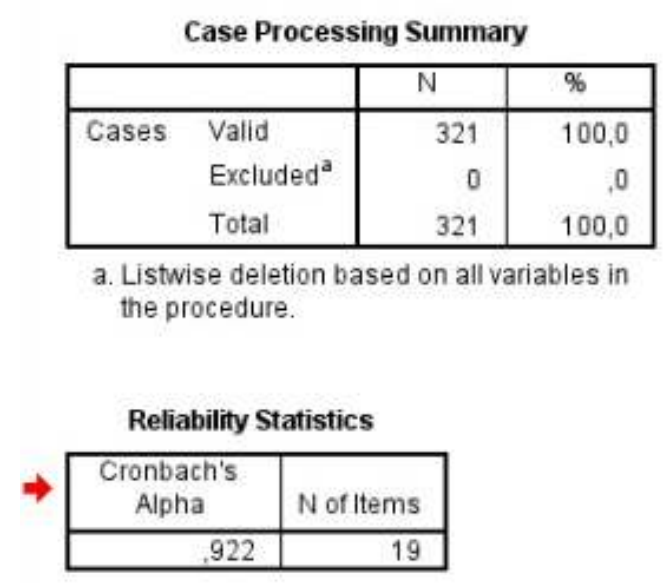

Figure 1 Results of Cronbach's Alpha Value

In this research, these are 19 attributes, based on results of Cronbach's Alpha Value is 0.922 (Figure 1). The value close to 1,0 point and it shows that questionnaire that used in this research is reliable. So that it has high reliability as a measure of the level of satisfaction of the beneficiaries who are respondents.

\section{Satisfaction Level with Top Two Box Method}

After getting the Cronbach's Alpha Value, we analyze Satisfaction with Top-Two Box Method. The results are:

Table 2 Results of Top Two Box Method

\begin{tabular}{|c|c|c|c|c|}
\hline No. & Factor & Attribute & Satisfaction & Avg. \\
\hline 1 & \multirow{5}{*}{ Tangible } & Provide scholarship program information & $99.07 \%$ & \multirow{5}{*}{$97.69 \%$} \\
\hline 2 & & $\begin{array}{l}\text { Face-to-face survey or making contact by } \\
\text { telephone }\end{array}$ & $98.44 \%$ & \\
\hline 3 & & $\begin{array}{l}\text { The scholarship form can be filled out } \\
\text { easily }\end{array}$ & $98.75 \%$ & \\
\hline 4 & & $\begin{array}{l}\text { Coaching is carried out according to the } \\
\text { time schedule }\end{array}$ & $95.64 \%$ & \\
\hline 5 & & $\begin{array}{l}\text { There is evidence of assistance / } \\
\text { disbursement of funds }\end{array}$ & $96.57 \%$ & \\
\hline 6 & \multirow{4}{*}{ Reliability } & $\begin{array}{l}\text { Administrative completeness is checked } \\
\text { carefully }\end{array}$ & $99.38 \%$ & \multirow{4}{*}{$98.29 \%$} \\
\hline 7 & & The coaching program is very helpful & $99.38 \%$ & \\
\hline 8 & & $\begin{array}{l}\text { Scholarship requirements can be fulfilled } \\
\text { easily }\end{array}$ & $98.75 \%$ & \\
\hline 9 & & Scholarships are sufficient to meet needs & $95.64 \%$ & \\
\hline 10 & \multirow{3}{*}{ Responsiveness } & $\begin{array}{l}\text { Quick response to questions that arise } \\
\text { from beneficiaries }\end{array}$ & $99.07 \%$ & \multirow{3}{*}{$98.60 \%$} \\
\hline 11 & & $\begin{array}{l}\text { Provides answers / solutions to questions } \\
\text { that arise from beneficiaries }\end{array}$ & $99.07 \%$ & \\
\hline 12 & & $\begin{array}{l}\text { Giving suggestions and advice in providing } \\
\text { services }\end{array}$ & $99.07 \%$ & \\
\hline
\end{tabular}




\begin{tabular}{|c|c|c|c|c|}
\hline No. & Factor & Attribute & Satisfaction & Avg. \\
\hline 13 & & $\begin{array}{l}\text { Scholarships are accepted according to the } \\
\text { amount that is informed }\end{array}$ & $97.20 \%$ & \\
\hline 14 & \multirow{3}{*}{ Assurance } & $\begin{array}{l}\text { Requests for incomplete administrative } \\
\text { documents with good communication }\end{array}$ & $99.38 \%$ & \multirow{3}{*}{$97.72 \%$} \\
\hline 15 & & $\begin{array}{l}\text { In conducting surveys, program managers } \\
\text { do it in polite language }\end{array}$ & $99.69 \%$ & \\
\hline 16 & & Scholarships distribution on time & $94.08 \%$ & \\
\hline 17 & \multirow{3}{*}{ Empathy } & Data verification with politely not coercion & $99.38 \%$ & \multirow{3}{*}{$98.75 \%$} \\
\hline 18 & & $\begin{array}{l}\text { Communication with program managers is } \\
\text { also carried out when there is a problem } \\
\text { with the mustahik }\end{array}$ & $98.44 \%$ & \\
\hline 19 & & $\begin{array}{l}\text { Program manager is always accompanying } \\
\text { during the scholarship period }\end{array}$ & $98.44 \%$ & \\
\hline \multicolumn{4}{|c|}{ Average } & $98.18 \%$ \\
\hline
\end{tabular}

In this result, the overall data of Beneficiaries satisfaction is $98.18 \%$. With satisfaction percentage of Communication Service is higher than Scholarship Management. The highest score of satisfaction item is using polite language in conducting survey. It shows that beneficiaries feel comfort with the language used. The lowest score is punctually of scholarship distribution. This is because BAZNAS has to collect funds first before distributing zakat funds to scholarship recipients. When the collection of zakat funds has problems, there will be a possibility that the scholarships are not given on time. And the Highest Score of Satisfaction factor is Empathy.

\section{Correlation Test}

From that data above (Table 2) we classify it into 3 classifications. The classification is Gender, Age, and Level of Education.

a. Gender

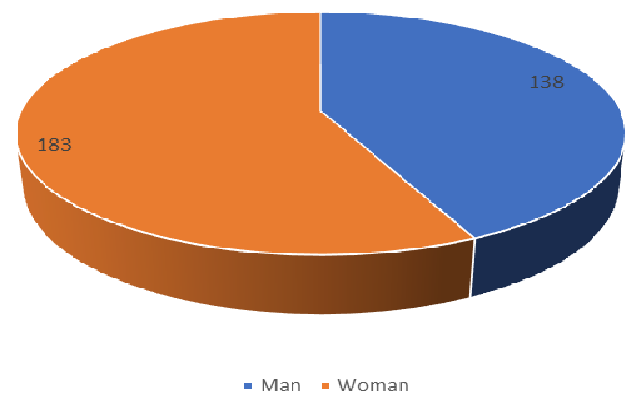

Figure 2 Gender Ratio

From this data it can be seen that women who filled out the most online questionnaires were women. An the satisfaction results is described below.

Table 3 Satisfaction Results based on Gender

\begin{tabular}{|l|c|c|}
\hline \multicolumn{1}{|c|}{ Gender } & Satisfaction & Dissatisfaction \\
\hline Man & $98.67 \%$ & $1.33 \%$ \\
\hline Woman & $97.81 \%$ & $2.19 \%$ \\
\hline
\end{tabular}

In this data, the satisfaction of Man is higher than woman. For correlation test gender with satisfaction level, we used SPSS method for measurement, and the results is described below. 


\begin{tabular}{|c|c|c|c|c|}
\hline \multicolumn{5}{|c|}{ Correlations } \\
\hline & & & Gender & $\begin{array}{c}\text { Satisfaction_ } \\
\text { Level }\end{array}$ \\
\hline \multirow[t]{2}{*}{ Spearman's rho } & Gender & $\begin{array}{l}\text { Correlation Coefficient } \\
\text { Sig. (2-tailed) } \\
\mathrm{N}\end{array}$ & $\begin{array}{r}1,000 \\
321\end{array}$ & $\begin{array}{r}-, 036 \\
, 525 \\
321\end{array}$ \\
\hline & Satisfaction_Level & $\begin{array}{l}\text { Correlation Coefficient } \\
\text { Sig. (2-tailed) } \\
\mathrm{N}\end{array}$ & $\begin{array}{r}-, 036 \\
, 525 \\
321\end{array}$ & $\begin{array}{r}1,000 \\
321\end{array}$ \\
\hline
\end{tabular}

Figure 3 Correlation Test (Gender)

It shows that the value of correlation tes is 0.525 . The standard used for the correlation test is below 0.05 . So there's no correlation about gender and satisfaction.

b. Age

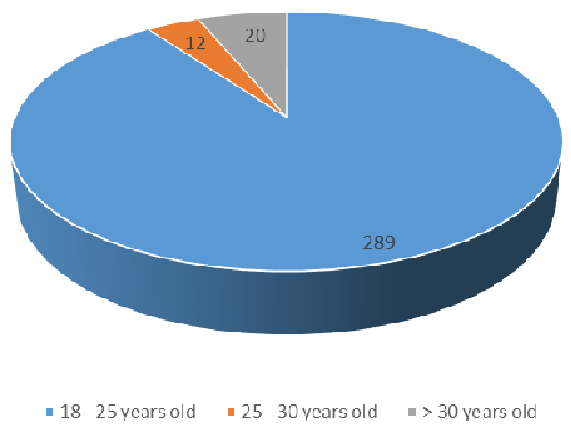

This data shows that Beneficiaries of BAZNAS Scholarship Agency mostly under 25 years old. Because focused on our program is for Bachelor Degree. The satisfaction results is

Table 4 Satisfaction Results based on Age

\begin{tabular}{|l|c|c|}
\hline \multicolumn{1}{|c|}{ Age } & Satisfcation & Dissatisfaction \\
\hline $18-25$ years old & $98.12 \%$ & $1.88 \%$ \\
\hline 25 - 30 years old & $99.56 \%$ & $0.44 \%$ \\
\hline$>30$ years old & $98.16 \%$ & $1.84 \%$ \\
\hline
\end{tabular}

The results of Correlation Test is described below.

Correlations

\begin{tabular}{|c|c|c|c|c|}
\hline & & & Years Old & $\begin{array}{c}\text { Satisfaction } \\
\text { Level }\end{array}$ \\
\hline \multirow[t]{2}{*}{ Spearman's rho } & Years Old & $\begin{array}{l}\text { Correlation Coefficient } \\
\text { Sig. (2-tailed) } \\
N\end{array}$ & $\begin{array}{r}1,000 \\
321\end{array}$ & $\begin{array}{r}-, 047 \\
, 401 \\
321\end{array}$ \\
\hline & Satisfaction_Level & $\begin{array}{l}\text { Correlation Coefficient } \\
\text { Sig. (2-tailed) } \\
N\end{array}$ & $\begin{array}{r}-, 047 \\
, 401 \\
321\end{array}$ & $\begin{array}{r}1,000 \\
321\end{array}$ \\
\hline
\end{tabular}

Figue 5 Correlation Test (Age)

It shows that the value of correlation test is 0.401 . So, there's no correlation about age and satisfaction. 
c. Level of Education

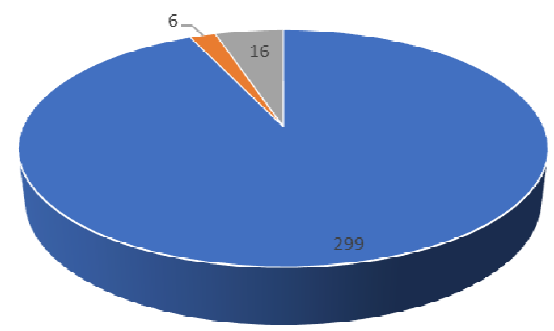

- $\mathrm{s} 1=\mathrm{s} 2 \mathrm{-s} 3$

Figure 6 Level of Education Ratio

As explained above, most of the BAZNAS Scholarship Agency's beneficiaries are from Bachelor degree. The results of satisfaction is described below.

Table 5 Satisfaction Results based on Education Level

\begin{tabular}{|l|c|c|}
\hline Education Level & Satisfaction & Dissatisfaction \\
\hline S1 & $98.12 \%$ & $1.88 \%$ \\
\hline S2 & $97.37 \%$ & $2.63 \%$ \\
\hline S3 & $99.67 \%$ & $0.33 \%$ \\
\hline
\end{tabular}

The data shows that postgraduate education (S3) have the highest satisfaction level $(99.67 \%)$. The second-high score is from bachelor degree (S1) and the lowest is postgraduate degree (S2). And the results of Correlation test is

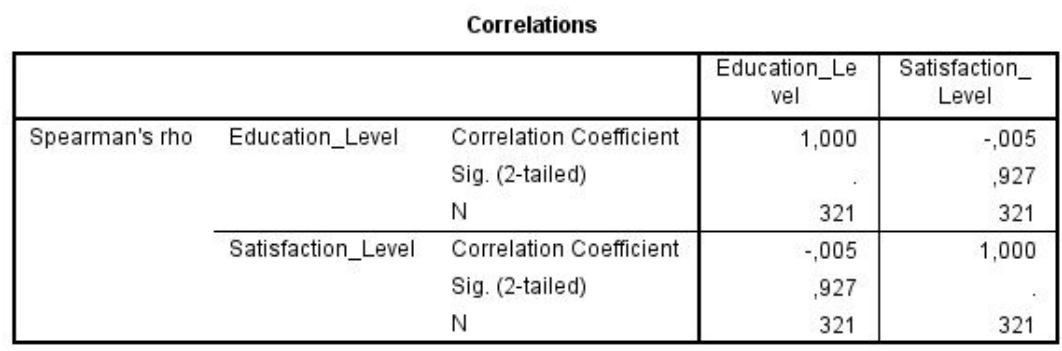

Figure 7 Correlation Test (Education Level)

It shows that the value of correlation test is 0.927 . So, there's no correlation about age and satisfaction.

\section{Effect for Zakat}

BAZNAS Scholarship Agency's beneficiaries are next future Muzakki (people who give zakat). Now they are still students. However, in the next few years after having a job or business, it is hoped that the recipients of this scholarship will become Muzakki. According to Yuliafitri and Khoiriyah, Pengaruh Kepuasan Muzakki, 215, satisfaction level of Muzakki have an impact to Muzakki's Loyalty. 


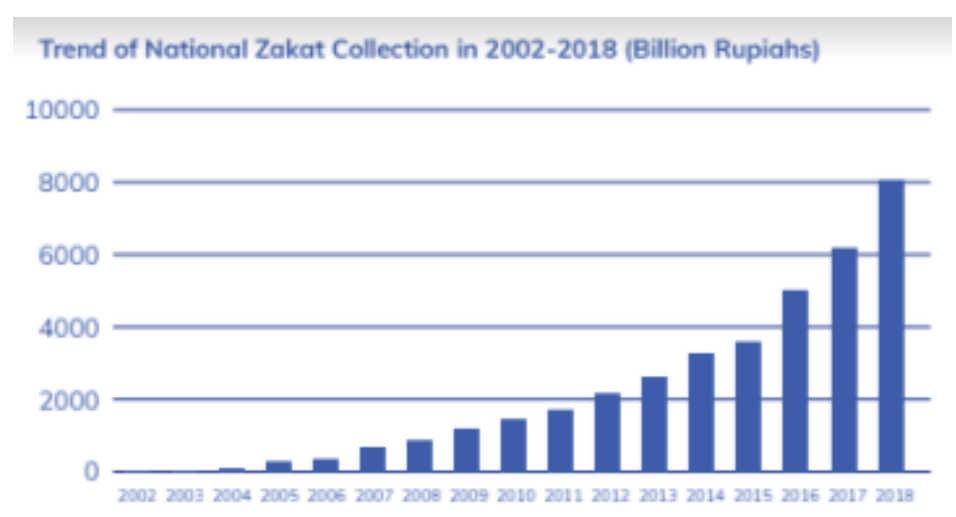

Figure 8 National Zakat Collection 2012-2018

(Center of Strategic Studies, Indonesia Zakat Outlook 2020, 34)

This data shows that zakat will experience growth every year. Therefore, it is important to maintain satisfaction and trust in the community including the beneficiaries who will become muzakki in the future.

\section{E. Conclusion}

Based on the objectives and analysis used in this study, it can be concluded that:

1. BAZNAS Scholarship Agency has good Communication Service and Scholarship Mangement with overall $98.19 \%$ rate of satisfaction level with the highest score of satisfaction item is using polite language and the lowest score is punctuality of scholarship distribution. BAZNAS Scholarship Agency must improve the scholarship management system, especially in the scholarship distribution time.

2. The highest satisfaction factor score is Empathy.

3. These are no correlation about Gender, Age, and Education Level with Satisfaction Score.

4. It is important to maintain satisfaction and trust in the community including BAZNAS Scholarship Agency's beneficiaries who will become muzakki in the future.

\section{References}

Abu Bakar, Adnan. “Pemberdayaan Zakat untuk Pendidikan.” Jurnal Nur El-Islam 2, no. 1 (2015).

Asmirawati. "Pengaruh Pemberian Beasiswa terhadap Motivasi Belajar Mahasiswa Jurusan Manajemen Pendidikan Islam Fakultas Tarbiyah dan Keguruan Universitas Islam Negeri Alauddin Makassar." Bachelor Minithesis. Makassar: Universitas Islam Negeri Alauddin, 2016.

Canggih, Clarashinta; Fikriyah, Khusnul; and Yasin, Ach. "Potensi dan Realisasi Dana Zakat Indonesia." Al-Uqud: Journal of Islamic Economic 1, no. 1 (Januari 2017): 14-26.

Center of Strategic Studies - The National Zakat Board. Indonesia Zakat Outlook 2020. Jakarta: Center of Strategic Studies - The National Zakat Board, 2020.

Citra, Maria; Lubis, Nawarizul; and Nurseto, Sendang. "Analisis Kepuasan Pelanggan Atas Kualitas Pelayanan Blackberry Internet Service Provider Telkomsel (Studi Kasus pada 100 Pengguna Blackberry Internet Service Provider Telkomsel di Kota Semarang)." Diponegoro Journal of Social and Politic (2013): 1-7.

Hakim, Arif Rahman; Arif, Suyud; and Baia, Hidayah. "Peran Zakat dalam Pembangunan Pendidikan (Studi Kasus Pendayagunaan Zakat Bidang Pendidikan Dompet Dhuafa Daarut Tahud Cabang Bogor)." Al-Infaq: Jurnal Ekonomi Islam, Vol. 5 No. 2 (September, 2014): 243-272.

Hikmat, Harry. Strategi Pemberdayaan Masyarakat, Bandung: Humaniora Utama Press. 2010. 
Lauw, Jessica and Kunto, Yohanes Sondang. "Analisa Pengaruh Kualitas Layanan Terhadap Kepuasan Pelanggan di the Light Cup Café Sruabaya Town Square dan The Square Surabaya." Jurnal Manajemen Pemasaran 1, no. 1 (2013).

Lembaga Beasiswa BAZNAS. Pedoman Beasiswa Cendekia Badan Amil Zakat Nasional: Kategori Dalam Negeri. 2020.

Lembaga Beasiswa BAZNAS. Profil Lembaga Beasiswa BAZNAS. 2020.

Ma'sum, Robbach. "Penerapan Pengelola Zakat Melalui Pendidikan." Jurnal Ilmu Pendidikan 4, no. 2 (Juli-Desember 2015).

Maharani, Putri Hanik S.; Fadhil, Muhammad; and Priyanti. "Impact Assessment of the BAZNAS Scholarship Program with Social Return of Invesment Approach in Several Universities." International Journal of Zakat and Islamic Philantrophy, Kedah, Malaysia (March, 2020).

Mardiyanti; Purmaningsih, Ninik; and Tjitropranoto, Prabowo. "Effectiveness of the Scholarship Program to Improve Student Achievement (The Case of Grantess Beastudi Etos at Jabodetabek)." Jurnal Penyuluhan 1, no. 1 (Maret, 2014).

Nana Mintarti, "Portraits and Challenges of Today's Education" Republika (Jakarta), January 12, 2018.

Qardawi, Yusuf. Hukum Zakat. Rev.ed. Jakarta: Litera Antar Nusa (2011).

Rachmawati, Annisa Dita; Zain, Ismaini; and Yahya, Kresnayana. "Analisis Statistik Kepuasan Pelanggan Terhadap Service Quality Unit Pembangkit PT. Pembangkit Jawa-Bali." Jurnal Sains dan Seni ITS 1, no. 1 (September 2012).

Yuliafitri, Indri and Khoiriyah, Asma Nur. "Pengaruh Kepuasan Muzakki, Transparansi, dan Akuntabilitas pada Lembaga Amil Zakat Terhadap Loyalitas Muzakki (Studi Persepsi Pada LAZ Rumah Zakat)." Jurnal Ekonomi Islam 7, no. 2 (Juli-Desember 2016): 205-218. 